\title{
Księga Ławnicza w życiu późnośredniowiecznego
} Pleszewa (1494-1501)

\footnotetext{
Sredniowieczne prawo, któremu w swoich pracach tak wiele uwagi poświęcił prof. Jacek Matuszewski, niestety coraz rzadziej staje
} się przedmiotem zainteresowania historyków prawa. Tymczasem jeszcze wiele kwestii wymaga szczegółowego zbadania, przykładowo nadal nie jest jasne, jaką rolę odgrywały księgi sądowe w życiu średniej wielkości miasta w późnym średniowieczu. Dzieje się tak ze względu na lakoniczność podstawy źródłowej, która nie dostarcza zbyt licznych bezpośrednich informacji w tym zakresie. W niniejszym artykule podjęta jednak zostanie próba wyjaśnienia tego problemu, oparta na analizie najstarszych 65 wpisów (z lat 1494-1501) z pleszewskiej Księgi wójtowskiej i ławniczej 1494-15541. Należy zauważyć, że rolę księgi ławniczej w życiu Pleszewa przełomu XV i XVI stulecia trzeba analizować w kilku aspektach: poprzez próbę wyjaśnienia, jaka była jej rola dla mieszkańców miasta i okolicy, jaka dla prowadzącej ją instytucji, wreszcie czy miała ona także pewne

${ }^{1}$ Archiwum Państwowe w Poznaniu, Akta miasta Pleszew, sygn. I 10. Opis i charakterystykę księgi przedstawili A. Warschauer oraz A. Kozak. Zob. A. Warschauer, Die mittelalterlichen Stadtbücher der Provinz Posen, "Zeitschrift der Historischen Gesellschaft für die Provinz Posen” 1896, t. XI, s. 379-382; A. Kozak, Wójtowie i ławnicy późnośredniowiecznego Pleszewa (1494-1519), „Rocznik Pleszewski” 2012, s. 198. Informacje o zachowanych w Polsce księgach ławniczych i wójtowsko-ławniczych, ich charakterystyce i treści oraz edycjach źródłowych podaje A. Bartoszewicz, Piśmienność mieszczańska w późnośredniowiecznej Polsce, Warszawa 2012, s. 88-98 oraz H. Samsonowicz, Średniowieczne ksieggi sadowe matych miast w Polsce, [w:] Homines et societas. Czasy Piastów i Jagiellonów. Studia ofiarowane Antoniemu Gasiorowskiemu w sześćdziesiąta piata rocznice urodzin, red. T. Jasiński, T. Jurek, J. M. Piskorski, Poznań 1997, s. 479-484. Pomocniczo wykorzystano w niniejszej pracy zapisy pleszewskiej księgi radzieckiej z lat 1428-1563, częściowo wydanej już drukiem: Najdawniejsze zapiski z księgi miejskiej Pleszewa (1428-1444), wyd. T. Jurek, Poznań 2011; Najstarsza pleszewska księga radziecka. Zapiski z lat 1485-1519, wyd. A. Kozak, Poznań 2014; Prawo magdeburskie miasta Pleszewa, wyd. W. Maisel, „Studia i Materiały do Dziejów Wielkopolski i Pomorza" 1963, t. VIII, z. 1 [15], s. 67-82. 
znaczenie dla właścicieli miasta ${ }^{2}$. Wnioski wyprowadzane będą głównie na podstawie przesłanek pośrednich, takich jak wskazanie tematyki wpisów, wyznaczenie kręgu osób, których sprawy wnoszone były do księgi oraz określenie ewentualnych barier w dostępie do niej.

Szczegółowe rozważania nad rolą pleszewskiej księgi ławniczej należy rozpocząć od przedstawienia tematyki wnoszonych do niej wpisów. Największą jej część stanowią zapiski dotyczące przeniesienia własności nieruchomości (domy, browary, młyny, parcele, pola, ogrody), których jest aż $21^{3}$, warto jednak pamiętać, że liczne rezygnacje wpisano również (wbrew praktyce obserwowanej $\mathrm{w}$ innych miastach ${ }^{4}$ ) do prowadzonej równolegle księgi radzieckiej ${ }^{5}$. Nieco mniej, bo 13, jest wpisów opisujących ugody $^{6}$. Zawierane były one najczęściej przy pomocy jednaczy, w obecności wójta i ławników, w dwóch zaś przypadkach jej treść zatwierdzili wybrani przez stronę sędziowie polubowni ${ }^{7}$. Ugody były umacniane przez karę umowną oraz poręczycieli ${ }^{8}$. Księga ławnicza zawiera również osiem zapisek dotyczących gajenia wielkich roków sądowych ${ }^{9}$, siedem poświadczających oprawy majątkowe (umowy o dziedziczenie pomiędzy małżonkami oraz jedna oprawa wienna) ${ }^{10}$, cztery dotyczące długów (potwierdzenia istnienia zobowiązania oraz informacje o ich spłacie $)^{11}$, trzy wpisy traktujące o rozliczeniach spadkowych ${ }^{12}$, dwie sprawy sporne ${ }^{13}$,

${ }^{2}$ Na gruncie analizy ksiąg wiejskich zauważono, że pozwalały one właścicielom sprawować kontrolę nad obrotem ziemią. O księgach wiejskich zob. S. Grodziski, Księgi sadowe wiejskie (Zasięg terytorialny i geneza), CPH, 1960, t. XII, s. 85-139; L. Łysiak, W sprawie genezy ksiag sądowych wiejskich, CPH, 1962, t. XIV, z. 2, s. 175-194; J. Słowiński, Kancelarie wsi małopolskich od końca XIV do schyłku XVIII wieku, „Studia Źródłoznawcze” 1991, t. XXXI, s. 25-35; ostatnio też T. Wiślicz, Księgi sadowe wiejskie z XV wieku, [w:] Świat średniowiecza. Studia ofiarowane Profesorowi Henrykowi Samsonowiczowi, red. A. Bartoszewicz, G. Myśliwski, J. Pysiak, P. Żmudzki, Warszawa 2010, s. 290-298.

${ }^{3}$ Księga wójtowska i ławnicza..., s. 4-5, 9, 12-14, 16-17, 18-19, 23-25, 27-38, 40, 42, 43.

${ }^{4}$ W. Maisel, Sadownictwo miasta Poznania do końca XVI wieku, Poznań 1961, s. 73.

${ }^{5}$ Ksiega radziecka 1428-1563 zawiera dla lat 1485-1519 aż 25 tego typu wpisów, stanowiących około $20 \%$ wniesionych do niej w tym czasie zapisek. Zob. Najstarsza pleszewska..., nr 7, 8, 10, 16, 17, 25, 40, 43, 45, 49, 55, 57, 58, 61, 63, 64, 68, 79, 84, 88, 91, 95, 101, 106, 127.

${ }^{6}$ Księga wójtowska i ławnicza..., s. 2-3, 6-8, 10-18, 20-23, 39.

${ }^{7}$ Tamże, s. 6, 8, 10-16, 20 - jednacze; s. 21-23, 39 - sędziowie polubowni.

${ }^{8}$ Tamże, s. 6, 8, 10-12, 17-18, 20-23, 39 - kara umowna; s. 17-18, 39 - poręczyciele.

${ }^{9}$ Tamże, s. 3, 10, 11, 30, 41-63.

10 Tamże, s. 9, 15, 19-21, 25-27, 31-32, 38-39. W latach 1485-1519 do księgi radzieckiej wniesiono aż 45 wpisów (37\%) dotyczących opraw posagu i wiana. Zob. Najstarsza pleszewska..., nr 3, 5, 6, 14, 15, 18, 23, 24, 26-28, 30, 35-37, 39, 41, 42, 47, 51-53, 56, 60, 62. 66, $67,69,70,72,73,76,80,83,85,99,100,108,109,112-117$.

${ }^{11}$ Tamże, s. 1-3, 6-7, 10.

12 Tamże, s. 16, 26, 40.

${ }^{13}$ Tamże, s. 33-34, 41. 
taką samą liczbę informacji o uiszczeniu $\operatorname{kar}^{14}$ i o wstawiennictwie przed sądem ${ }^{15}$. Wreszcie trzy pozostałe zapiski dotyczą kolejno: ustanowienia opiekunów mających troszczyć się o majątek osieroconych dzieci zmarłego Marcina Drozda (zostali nimi bracia zmarłego Szymon Drozdek i Mikołaj Szytko), rezygnacji z posiadania domu (Wojciech Przezmózgi kupił od Anny Jajkowej dom za 30 grzywien, wpłacił „zadatek” w wysokości 1/3 umówionej kwoty, gdy jednak został wezwany do uiszczenia reszty, zdecydował się opuścić dom i zrzec dalszych roszczeń do niego) oraz informacji o powołaniu świadków w sprawie sporu Piotra Napadły i Katarzyny Napadłowej (próbowano ustalić, czy Katarzyna zobowiązała się dać swojemu zięciowi Piotrowi ruchomości i nieruchomości, w zamian za dwie grzywny i obowiązek utrzymania jej aż do śmierci) ${ }^{16}$. Udział procentowy poszczególnych kategorii wpisów w księdze przedstawia wykres 1.

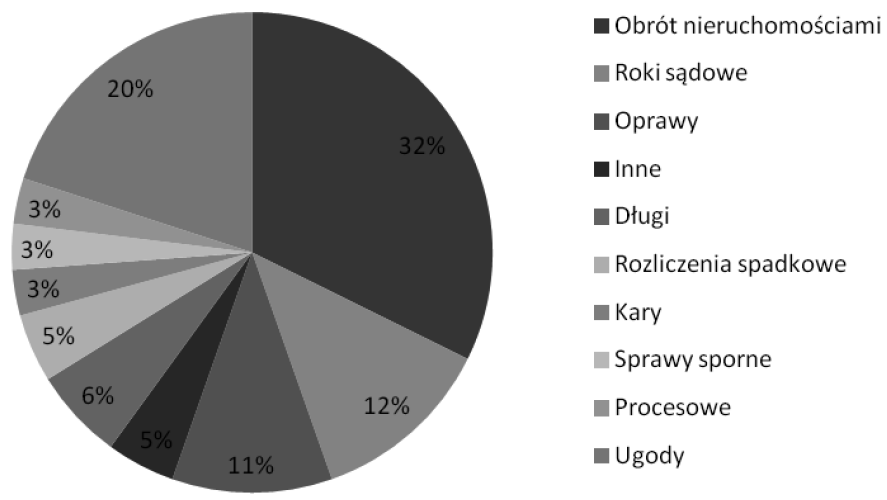

Wykres 1. Tematyka wpisów do pleszewskiej księgi ławniczej (1494-1501) Źródło: oprac. własne.

Porównanie tematyki wpisów pleszewskich z tymi, które były wnoszone do ksiąg sądowych innych miast zbliżonej wielkości pozwala wskazać, że treść analizowanego źródła jest typowa i nie wyróżnia się w żaden sposób na ich tle (może poza zupełnym brakiem wzmianek o rencie wykupnej oraz testamentach $)^{17}$.

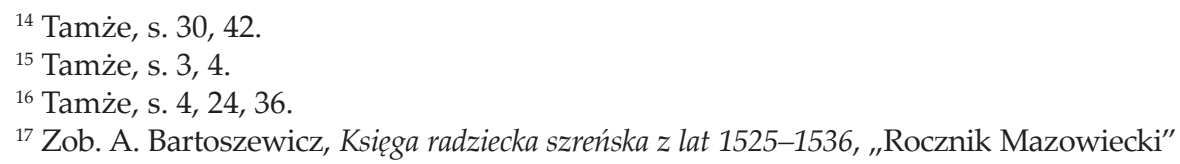
2001, t. XIII, s. 72; taż, Ksiegi sadowe Nowej Wsi (Łobzowskiej) z drugiej połowy XV wieku, „Studia Źródłoznawcze" 2001, t. XXXIX, s. 119; J. Przeracki, Księga ławnicza sadu przedmiejskiego Nowego Miasta Torunia z lat 1444-1457, [w:] Studia nad dziejami miast i mieszczaństwa w średniowieczu, t. II, Studia ofiarowane Profesorowi Antoniemu Czacharowskiemu w sześćdziesiąta piata rocznicę urodzin i czterdziestolecie pracy naukowej, red. R. Czaja, J. Tandecki, Torun 1996, s. 312. Księga radziecka notuje natomiast dwa testamenty w pełnym brzmieniu, trzy streszczenia oraz kilka dalszych 
Spostrzeżenie o zbliżonej tematyce miejskich ksiąg sądowych, niezależnej od miejsca, w którym były one prowadzone, pozwala na wysnucie ważnych wniosków: spośród licznych spraw przedkładanych przez mieszkańców przed organy władz miejskich można wyróżnić takie, które $\mathrm{w}$ pojęciu XV-wiecznych mieszczan wymagały uwiecznienia $\mathrm{w}$ formie wpisu do księgi. Są to przede wszystkich zeznania informujące o przeniesieniu własności nieruchomości, które niemal zawsze stanowią najliczniejszą grupę zapisek, działy majątkowe pomiędzy spadkobiercami, wpisy dotyczące długów, wreszcie oprawy oraz niereprezentowane w pleszewskiej księdze ławniczej testamenty.

Potrzebę utrwalania na piśmie akurat tych kategorii spraw tłumaczyć może kilka przyczyn. W przypadku przenoszenia własności nieruchomości należy pamiętać, że wpis miał charakter wieczysty, co podkreślano w treści zapisek wskazując, że własność przenoszona jest nie tylko na nabywcę, ale także i na jego następców (s. 4: „Providus Jacobus serifex - recognovit, quia vendidit et resignavit domum suam - ita longe et late, prout se prefata domus inter vicinos habet et locat, pro novem marcis - provido Johanne Makowka suisque successoribus legittimis"), stąd nie może dziwić chęć zabezpieczenia transakcji tego typu trwałym dowodem. Znaczenie w tym przypadku ma zapewne również okoliczność, że w miastach prywatnych właściciele (bądź ich urzędnicy) pobierali opłatę od transakcji przeniesienia własności nieruchomości, czyli tak zwane wzdawne ${ }^{18}$. Byli więc żywotnie zainteresowani rejestrowaniem przez władze miejskie spraw tego typu, co pozwala nawet przypuszczać, że $\mathrm{w}$ prawie miejskim, tak jak $\mathrm{w}$ prawie ziemskim, mógł istnieć obowiązek wpisywania do ksiąg rezygnacji.

W przypadku pozostałych kategorii wpisów warto zauważyć, że uwieczniały one sprawy, które z jednej strony można śmiało zaliczyć do najważniejszych w życiu mieszczan (a zatem dotyczących sfery interesów gospodarczych w przypadku długów oraz kwestii majątkowo-rodzinnych przy działach spadkowych i testamentach), a z drugiej były częstym powodem sporów (w przypadku testamentów spadkodawcy często wprost podawali chęć uniknięcia sporów jako motyw sporządzenia testamentu). Trzeba pamiętać, że księgi miejskie miały niewątpliwie moc dowodową na gruncie tak zwanego prawa niemieckiego, wpis mógł więc gwarantować silniejsze zabezpieczenie własnych interesów oraz pomoc władz miejskich (które zatwierdzały swoim autorytetem wpisywane do ksiag sprawy) we właściwym rozstrzygnięciu ewentualnego konflik-

wzmianek o nich. Zob. Najstarsza pleszewska..., nr 20, 50, 90, 94, 105; A. Kozak, Testamenty mieszczan pleszewskich w późnym średniowieczu, „Rocznik Pleszewski” 2013, s. 155-163.

${ }^{18}$ Informacje o pobieraniu wzdawnego w Pleszewie: Księga wójtowska i ławnicza..., s. $18-19,21-23$. 
$\mathrm{tu}^{19}$. Tezę tę wydają się potwierdzać noty o ponoszonych przez strony opłatach sądowych za wpis do księgi i fatygę pisarza, które były zasadniczo wnoszone przez osobę, która na przedmiotowej transakcji zyskała (np. nabywcę nieruchomości). Pamiętać też trzeba, że wpisy, które z jakichś względów utraciły swoją aktualność (chociażby z powodu spłaty zapisanego w nich długu), były przez kancelarię miejską kasowane ${ }^{20}$.

Tezę o dokonywaniu wpisów w celach dowodowych potwierdza dalsza analiza treści księgi. Po pierwsze stosunkowo niewielką doniosłość miały wpisy mające znaczenie wyłącznie dla sądu i urzędu ławniczego, do których można zaliczyć chociażby informujące o gajeniu (zwoływaniu) wielkich roków sądowych, sprawach spornych, spłacie nałożonych na mieszczan kar oraz o stawiennictwie strony na posiedzeniach (stanowiły one zaledwie $20 \%$ wszystkich wpisów). Znacznie częściej odnotowywano za to sprawy niesporne, w których ława miejska występowała nie tyle jako sąd, ale jako urząd zaufania publicznego. Głównym celem wnoszenia tego rodzaju wpisów było poświadczanie treści czynności prawnych oraz potwierdzanie ich zgodności z prawem miejskim (miało to szczególne znaczenie w przypadku ugód). Twierdzenie o dużej roli dowodowej księgi wydają się potwierdzać też zapiski ze s. 21-23 i 39, które nie pochodzą od władz miejskich, lecz od zebranych ad hoc sądów polubownych. W tym przypadku konieczne było niewątpliwie podjęcie dodatkowych starań, żeby treść rozstrzygnięcia została wciągnięta do księgi ławniczej. Niewątpliwie nie uczyniono by tego, gdyby nie gwarantowało to zainteresowanym stronom lepszego zabezpieczenia ich interesów.

Nie można zapominać też, że zapisy w księdze ławniczej służyły nie tylko mieszkańcom Pleszewa, ale i samej instytucji prowadzącej księgę. Nie ulega wątpliwości, że fakt rejestrowania w niej spraw sądowych i poszczególnych stadiów postępowania ułatwiał funkcjonowanie ławy ${ }^{21}$. Użycie pisma odciążało pamięć wójta i ławników, którzy w innych sytuacjach musieliby w przypadku sporu stawać przed sądem i informować na podstawie własnej pamięci o treści zdziałanych wobec nich czynności prawnych ${ }^{22}$.

${ }^{19} \mathrm{~J}$. Łosowski, Kancelarie miast szlacheckich województwa lubelskiego od XV do XVIII wieku, Lublin 1997, s. 75. Zob. również Najdawniejsze zapiski z księgi miejskiej Pleszewa (14281444), wyd. T. Jurek, Poznań 2011, nr 4, 44, gdzie strony procesu powoływały się na wpisy w księgach miejskich.

${ }^{20}$ Księga wójtowska i ławnicza..., s. 1, 6.

${ }^{21} \mathrm{~J}$. Łosowski, Dokument i księga wpisów w społecznościach małych miast okresu staropolskiego. Problem funkcji, [w:] Kultura piśmienna średniowiecza i czasów nowożytnych. Problemy $i$ konteksty badawcze, red. P. Dymmel, B. Trelińska, Lublin 1998, s. 151.

${ }^{22}$ Ze względu na ten obowiązek wójt i ławnicy pobierali opłatę zwaną pamiętne (arra, memoriale). Zob. Księga wójtowska i ławnicza..., s. 10-12. 
Po wskazaniu zakresu spraw, jakie wpisywane były do księgi i korzyści wiążących się z tym faktem, można przyjrzeć się kręgowi ludzi, którzy zostali utrwaleni jako strony spraw wnoszonych na forum ławy miasta Pleszewa. Co oczywiste, zdecydowaną większość tego grona stanowili mieszczanie pleszewscy. Warto jednak zauważyć, że - podobnie jak w przypadku księgi radzieckiej ${ }^{23}$ - nie byli oni jedynymi użytkownikami księgi. Przed ławą w charakterze stron występowali też mieszkańcy (wymienieni tu w kolejności chronologicznej) Trzebowej, Lutyni, Brześnicy, Galewa, Borzęcic, Taczanowa, Czarnuszki, Grabowa nad Prosną, Piekarzewa, Baranówka, Stawiszyna oraz Grudzielca ${ }^{24}$. Dodatkowo w innych rolach wspomniani są wójt kaliski i młynarz z Woli Duchownej. Odnotowano także dwóch mieszkańców z niezidentyfikowanych miejscowości Ruglicza i Ruchowo ${ }^{25}$. Nie-pleszewianie byli stronami w ośmiu sprawach, co stanowi około $12 \%$ wszystkich analizowanych zapisek, dodatkowo w dwóch przypadkach spawa toczyła się wyłącznie między przybyszami spoza miasta ${ }^{26}$. Listę i przedmiot spraw zestawiono $\mathrm{w}$ tabeli 1 , położenie geograficzne miejscowości pochodzenia stron ukazano na mapie 1.

Tabela 1. Osoby spoza Pleszewa będące stronami w sprawach przedstawianych ławie miejskiej Pleszewa

\begin{tabular}{|c|c|c|c|}
\hline Strona & Strona A & Strona B & Przedmiot sprawy \\
\hline 1 & Marcin z Trzebowej & Świętosław & spłata długu \\
\hline $1-2$ & $\begin{array}{c}\text { Michał młynarz } \\
\text { z Lutynii }\end{array}$ & Mikołaj ślusarz & spłata długu \\
\hline 6 & $\begin{array}{c}\text { Mikołaj de Ruglicza, } \\
\text { sługa Jana }\end{array}$ & Jan Krzyżan & $\begin{array}{c}\text { ugoda w sprawie spłaty } \\
\text { długu }\end{array}$ \\
\hline $6-7$ & Szymon z Brześnicy & Jan Krzyżan & spłata długu \\
\hline $7-8$ & $\begin{array}{c}\text { Jakub z Galewa z siostra } \\
\text { Jadwigą z Borzęcic }\end{array}$ & Michał Jajsz & $\begin{array}{c}\text { ugoda w sprawie } \\
\text { podziału spadku }\end{array}$ \\
\hline 8 & Jan de Ruchowo & Jan Krzyżan & $\begin{array}{c}\text { ugoda w sprawie } \\
\text { zwrotu długu }\end{array}$ \\
\hline 12 & Jan Hanusz z Grabowa & Paweł Hardy & $\begin{array}{c}\text { ugoda w sprawie spłaty } \\
\text { długu }\end{array}$ \\
\hline
\end{tabular}

${ }^{23}$ A. Kozak, Wstęp, [w:] Najstarsza pleszewska..., s. 22.

${ }^{24}$ Księga wójtowska i ławnicza..., s. 1-2, 6-8, 12-14, 14-18, 26, 36-38.

${ }_{25}$ Tamże, s. 6 (Ruglicza), 8 (Ruchowo), 12 (Kalisz), 19 (Wola Duchowna).

${ }^{26}$ Tamże, s. 17-18, 26. 


\begin{tabular}{|c|c|c|c|}
\hline 13-14 & $\begin{array}{c}\text { Marcin z Taczanowa; } \\
\text { Paweł z Czarnuszki - } \\
\text { szwagrowie Elżbiety }\end{array}$ & $\begin{array}{c}\text { Elżbieta, wdowa po } \\
\text { Janie Chudym }\end{array}$ & podział spadku \\
\hline $17-18$ & $\begin{array}{c}\text { Dorota Szostkowa } \\
\text { z Piekarzewa }\end{array}$ & $\begin{array}{c}\text { Jakub Jakuł } \\
\text { z Baranówka }\end{array}$ & podział spadku \\
\hline 26 & $\begin{array}{c}\text { Wojciech Knyszka } \\
\text { z Grudzielca }\end{array}$ & $\begin{array}{c}\text { Maciej Szabla sołtys } \\
\text { W Stawiszynie, brat } \\
\text { Wojciecha Knyszki }\end{array}$ & $\begin{array}{c}\text { ugoda w sprawie } \\
\text { podziału spadku }\end{array}$ \\
\hline $36-38$ & Jan Hanusz z Grabowa & Maciej Deksa & $\begin{array}{c}\text { sprzedaż domu } \\
\text { w Pleszewie }\end{array}$ \\
\hline
\end{tabular}

Uwaga: wyróżniono wpisy, w których stroną nie był żaden mieszczanin.

Źródło: oprac. własne.

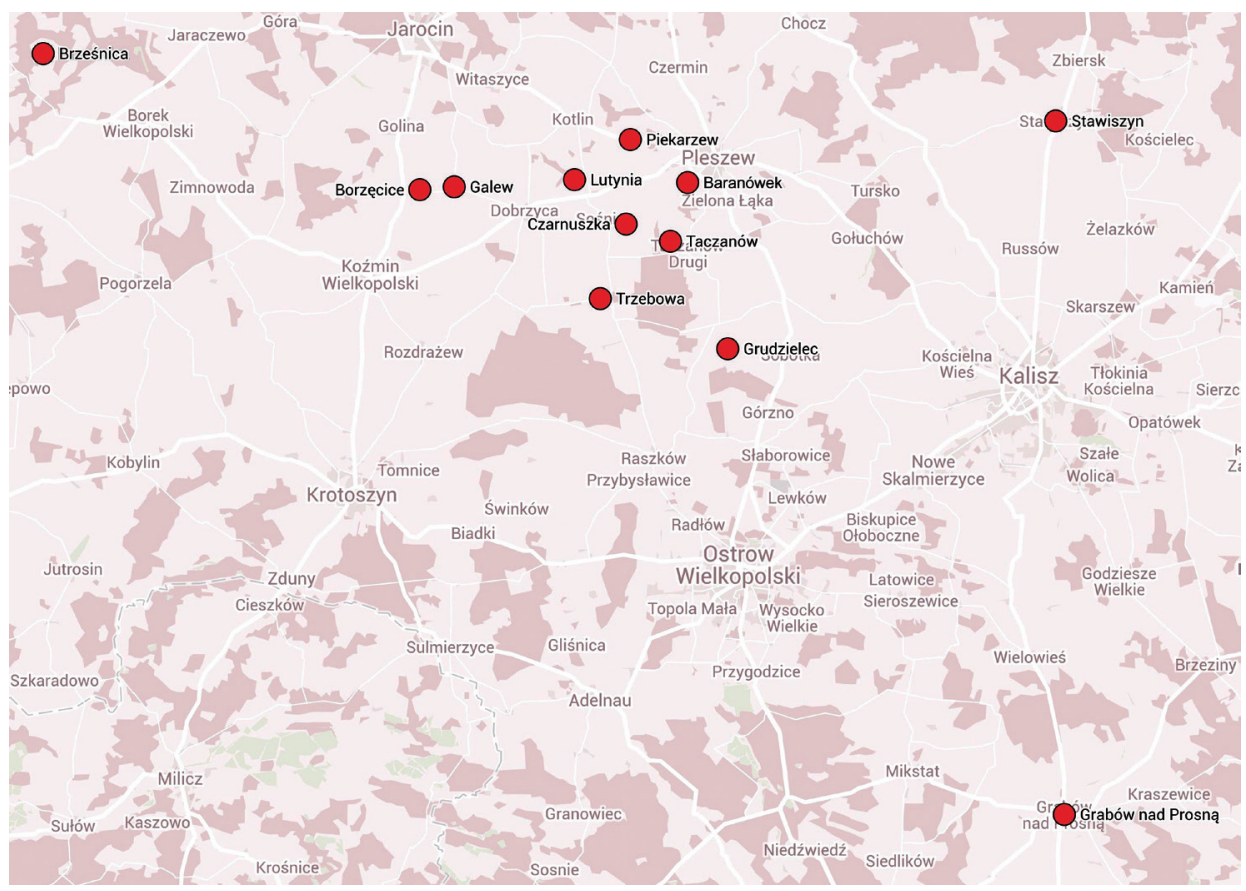

27 Zapiski ze s. 12 i 36-38 opisują typową scenę z życia średniowiecznego miasta: 1 lipca 1496 r. Paweł Hardy zwany Paszkiem zobowiązał się w ugodzie zawartej przy pomocy jednaczy zapłacić Janowi Hanuszowi z Grabowa nad Prosną 14 florenów, jednak kilka lat później (13 grudnia 1499 r.) zapisano, że Jan Hanusz sprzedaje dom nieżyjącego już Pawła „,nabyty ze względu na długi” (, ,providus Johannes dictus Hannus civis de Grabowo recognovit et per presentes recognoscit, quod vendidit <et resignavit> domum olim Pauli Hardi, aquisitam pro debito iure hereditario") mieszczaninowi pleszewskiemu Maciejowi Deksie za 12 grzywien (Janowi udało się zatem odzyskać dług nawet z pewnym zyskiem - zakładając, że floren stanowił równowartość około 3/4 grzywny). 
Analizując mapę łatwo można wyznaczyć zasięg oddziaływania pleszewskiego sądu ławniczego oraz jego księgi. Była ona istotna przede wszystkim dla ludzi mieszkających na zachód i południe od Pleszewa, w odległości nie większej niż 20 kilometrów od miasta (co stanowi odległość możliwą do przebycia pieszo w ciągu jednego dnia). Jednocześnie można zaryzykować twierdzenie, że ludzie mieszkający na wschód od niego udawali się ze swoimi sprawami przed sądy miejskie Kalisza (niestety piętnastowieczne księgi miejskie tego ośrodka nie zachowały się). Z drugiej strony skrupulatna lektura danych zestawionych w tabeli 1 pozwala na kolejne ustalenia. W większości przypadków za decyzją przedstawienia sprawy ławie miejskiej Pleszewa stał fakt, że jedną ze stron sprawy był mieszczanin pochodzący z tego miasta. Za najciekawsze należy uznać jednak wpisy ze stron 17-18 i 26, gdzie w ogóle nie występowali pleszewianie, lecz wyłącznie przybysze z innych miejscowości. W pierwszym przypadku byli to mieszkańcy podmiejskich wsi, na które Pleszew z pewnością silnie oddziaływał ${ }^{28}$, w drugim zaś znacznie bardziej oddalonych Grudzielca i Stawiszyna, dla których był on miejscem położonym $\mathrm{w}$ połowie drogi, co z pewnością było dogodne dla układających się stron.

Tytułem podsumowania tej części ustaleń można stwierdzić, że w większości przypadków zasięg oddziaływania sądu ławniczego był ściśle powiązany z rozległością interesów i koligacji rodzinnych samych pleszewian. Nie umniejsza to oczywiście znaczenia samej księgi, skoro osoby spoza miasta nie czyniły przeszkód, żeby „powierzyć jej” swoje sprawy.

Wskazanie, że nie tylko mieszkańcy Pleszewa stawali przed ławą miejska, budzi jednocześnie pytanie o przynależność stanową stron spraw zapisanych w księdze. Na podstawie analizy predykatów stanowych możemy wskazać, że najczęściej wpisy dotyczą rzecz jasna mieszczan i mieszczek (wyróżnianych predykatami stanowymi providus, honesta), jednak w niemalże $8 \%$ spraw jako strona występował szlachcic (nobilis), w jednym przypadku stroną był duchowny (honorabilis), wreszcie siedmiokrotnie przed sądem ławniczym występują chłopi (blisko 11\% wpisów $)^{29}$. Należy też dodać, że w zapisce ze s. 19 odnotowana jest czynność prawna pomiędzy dwoma szlachcicami, a we wpisach ze s. 35-36 i 40 to-

${ }^{28}$ Zauważyć trzeba, że Piekarzew i Baranówek należały wraz z Pleszewem do jednego klucza dóbr będącego w omawianym okresie własnością Tęczyńskich herbu Topór. Zob. J. Kurtyka, Tęczyńscy. Studium z dziejów polskiej elity możnowładczej w średniowieczu, Kraków 1997, s. 531, przyp. 15.

${ }^{29}$ Księga wójtowska i ławnicza..., s. 16, 18-19, 35-36, 40 - szlachta; s. 2-3 - duchowny; s. 1, 24-27, 35-36, 38-40 - chłopi. 
czą się sprawy szlachecko-chłopskie. Zagadnienie występowania osób spoza stanu mieszczańskiego przedstawia wykres 2 informujący o liczbie spraw, w których brali udział członkowie poszczególnych stanów oraz tabela 2, gdzie zestawione zostały wpisy, w których brały udział osoby spoza stanu mieszczańskiego.

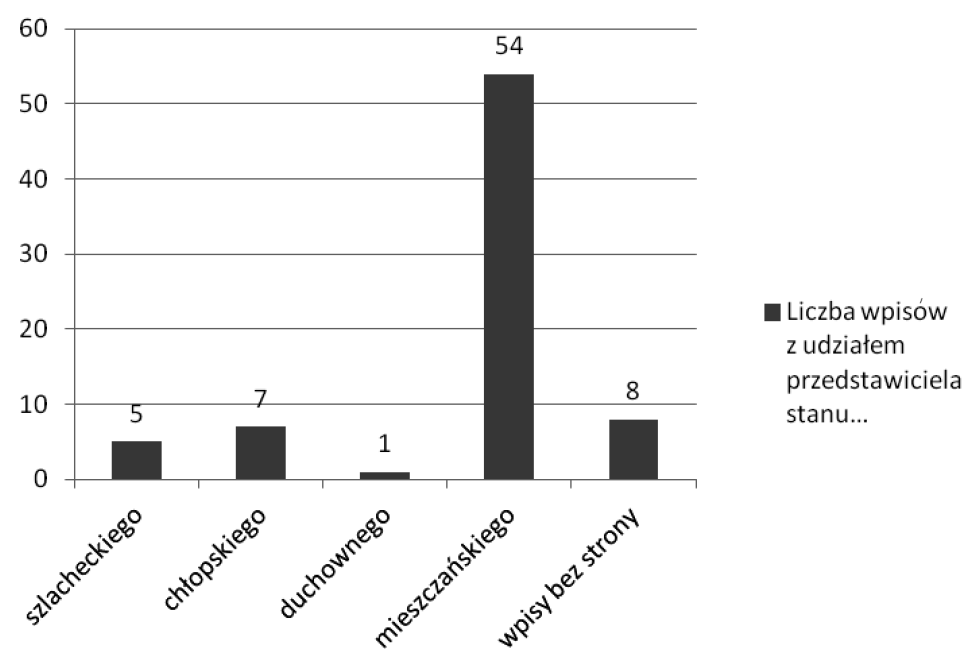

Wykres 2. Liczba wpisów do księgi z udziałem przedstawicieli poszczególnych stanów Źródło: oprac. własne.

Tabela 2. Sprawy z pleszewskiej księgi ławniczej, w których stronami były osoby innego stanu niż mieszczański

\begin{tabular}{|c|c|c|c|}
\hline Strona & Strona A & Strona B & Przedmiot sprawy \\
\hline $\mathbf{1}$ & $\mathbf{2}$ & $\mathbf{3}$ & $\mathbf{4}$ \\
\hline 1 & $\begin{array}{c}\text { pracowity Marcin } \\
\text { z Trzebowy }\end{array}$ & Świętosław & spłata długu \\
\hline $2-3$ & $\begin{array}{c}\text { czcigodny Tomasz } \\
\text { prezbiter }\end{array}$ & Marcin Smolarz & $\begin{array}{c}\text { ugoda dotycząca domu } \\
\text { Mikołaja Chadały }\end{array}$ \\
\hline 16 & $\begin{array}{c}\text { szlachetny Stanisław } \\
\text { Słodzki }\end{array}$ & Jan Skrobiróg & spłata długu \\
\hline $18-19$ & $\begin{array}{c}\text { szlachetny Jakub } \\
\text { Kamocki }\end{array}$ & Piotr Piórka & $\begin{array}{c}\text { sprzedaż domu } \\
\text { w Pleszewie }\end{array}$ \\
\hline 19 & $\begin{array}{c}\text { szlachetny Jakub } \\
\text { Kamocki }\end{array}$ & Maciej Lutyński & $\begin{array}{c}\text { sprzedaż domu } \\
\text { w Pleszewie }\end{array}$ \\
\hline
\end{tabular}


cd. tab. 2

\begin{tabular}{|c|c|c|c|}
\hline 1 & 2 & 3 & 4 \\
\hline $24-25$ & pracowity Wit garncarz & Marcin Pakuł & sprzedaż ogrodu \\
\hline $25-27$ & pracowity Jan Krzyk & $\begin{array}{c}\text { Agnieszka Pruska, żona } \\
\text { Jana }\end{array}$ & umowa o dziedziczenie \\
\hline 26 & $\begin{array}{c}\text { pracowity Wojciech } \\
\text { Knyszka }\end{array}$ & $\begin{array}{l}\text { Maciej Szabla, sołtys } \\
\text { w Stawiszynie, brat } \\
\text { Wojciecha Knyszki }\end{array}$ & $\begin{array}{l}\text { ugoda w sprawie } \\
\text { podziału spadku }\end{array}$ \\
\hline $35-36$ & $\begin{array}{c}\text { pracowity Błażej } \\
\text { młynarz }\end{array}$ & $\begin{array}{c}\text { szlachetny Wierzbięta } \\
\text { Bobrowiński }\end{array}$ & $\begin{array}{c}\text { wzdanie młyna w Łęgu } \\
\text { nad Prosną }\end{array}$ \\
\hline $38-39$ & $\begin{array}{c}\text { pracowity Grzegorz, } \\
\text { zięć Agnieszki, wraz } \\
\text { z żoną Dorota, córką } \\
\text { Agnieszki }\end{array}$ & Agnieszka Baryczkowa & oprawa posagu i wiana \\
\hline 40 & pracowity Jan Jarzanis & $\begin{array}{c}\text { szlachetny Dziersław } \\
\text { Lutyński }\end{array}$ & $\begin{array}{l}\text { sprzedaż domu } \\
\text { w Pleszewie }\end{array}$ \\
\hline
\end{tabular}

Źródło: oprac. własne.

Dane przedstawione schematycznie na wykresie 2 dowodzą niezbicie ponadstanowego charakteru pleszewskiego sądu ławniczego, w tym także jego księgi, której zapisy wydają się poważać nie tylko pleszewianie, ale również okoliczna szlachta oraz chłopi, mimo iż przynależeli oni do odmiennych systemów prawnych. Wiele wskazuje na to, że w takich sytuacjach największe znaczenie miała bliskość sądu i jego księgi, a nie prawo, według którego ów rozstrzygał sprawy (w szczególności w przypadkach, gdzie ława pełniła funkcje notarialne, a nie sądowe). Oczywiście najczęściej (patrz tab. 2) o wyborze pleszewskiej ławy decydowało to, że sprawa dotyczyła nieruchomości znajdującej się $\mathrm{w}$ mieście ${ }^{30}$ oraz fakt, że jedna ze stron była ściśle $\mathrm{z}$ nim związana $^{31}$. Zdarzało się jednak też, że przed wójtem i ławnikami stawały osoby, których nie sposób łączyć z Pleszewem, nie posiadające tu żadnych interesów ani rodziny ${ }^{32}$, co świadczyłoby właśnie o prestiżu, jakim cieszył się miejscowy sąd i jego księga oraz o ich ponadstanowym charakterze.

Warto spojrzeć również na strukturę społeczną mieszczan pleszewskich notowanych we wpisach. Tylko w $21,5 \%$ spraw uczestniczyli członkowie władz miejskich, co dowodzi, że wpis do księgi uważany był za cenny nie tylko przez członków elity miejskiej, niewątpliwie reprezentu-

\footnotetext{
${ }^{30}$ Tamże, s. 18-19, 40.

${ }^{31}$ Tamże, s. 1, 16, 24-25, 38-39.

${ }^{32}$ Tamże, s. 26, 35-36.
} 
jącej choćby minimalnie wyższy poziom wykształcenia i większą wrażliwość na kulturę pisma, ale przez całą gminę ${ }^{33}$. Teoretycznie dostęp do niej powinien być ograniczony przez fakt pobierania opłat "od księgi” oraz konieczność opłacenia pisarza, widocznie jednak ich wysokość nie przekraczała możliwości finansowych przeciętnego mieszczanina ${ }^{34}$.

Podsumowując należy stwierdzić, że pleszewska księga ławnicza odgrywała dużą rolę nie tylko w życiu późnośredniowiecznego miasta, ale również jego okolic. Przede wszystkim pełniła ona wobec mieszczan funkcje notarialne, poświadczając i umacniając dokonywane przez nich transakcje. Można równocześnie wskazać grupę spraw, w których wpis odgrywał istotniejszą rolę, zabezpieczając strony przed ewentualnymi konfliktami w dalekiej nawet przyszłości. Istotne jest też, że swoje sprawy polecali wpisać do niej nie tylko przedstawiciele miejscowej elity (członkowie władz miejskich), ale również przeciętni mieszczanie. Duże znaczenie księgi znamionuje również jej oddziaływanie poza miastem, co potwierdzają zapiski, w których stronami są mieszkańcy okolicznych miejscowości, będący przedstawicielami wszystkich stanów. Wreszcie nie można zapominać, że stanowiła ona rejestr transakcji przeniesienia własności nieruchomości, ważny dla właścicieli miasta ze względu na pobierane opłaty.

\section{Bibliografia}

Bartoszewicz A., Księga radziecka szreńska z lat 1525-1536, „Rocznik Mazowiecki” 2001, t. XIII, s. 69-78.

Bartoszewicz A., Księgi sądowe Nowej Wsi (Łobzowskiej) z drugiej połowy XV wieku, „Studia Źródłoznawcze” 2001, t. XXXIX, s. 115-131.

Bartoszewicz A., Piśmienność mieszczańska w późnośredniowiecznej Polsce, Warszawa 2012.

Grodziski S., Księgi sądowe wiejskie (Zasięg terytorialny i geneza), „Czasopismo Prawno-Historyczne" 1960, t. XII, s. 85-139.

Kozak A., Testamenty mieszczan pleszewskich w późnym średniowieczu, „Rocznik Pleszewski" 2013, s. 155-163.

Kozak A., Wójtowie i ławnicy późnośredniowiecznego Pleszewa (1494-1519), „Rocznik Pleszewski" 2012, s. 197-213.

Kurtyka J., Tęczyńscy. Studium z dziejów polskiej elity możnowładczej w średniowieczu, Kraków 1997.

Łosowski J., Dokument i księga wpisów w społecznościach małych miast okresu staropolskiego. Problem funkcji, [w:] Kultura piśmienna średniowiecza i czasów nowo-

\footnotetext{
${ }^{33}$ Tamże, s. 4-5, 9-11, 14-19, 24-25, 29-30, 36-38.

${ }^{34}$ Tamże, s. 10-11, 13-16, 23, 29-32, 36-38.
} 
żytnych. Problemy i konteksty badawcze, red. P. Dymmel, B. Trelińska, Lublin 1998, s. 151-164.

Łosowski J., Kancelarie miast szlacheckich województwa lubelskiego od XV do XVIII wieku, Lublin 1997.

Łysiak L., W sprawie genezy ksiag sadowych wiejskich, „Czasopismo Prawno-Historyczne" 1962, t. XIV), z. 2, s. 175-194.

Maisel W., Sadownictwo miasta Poznania do końca XVI wieku, Poznań 1961.

Najdawniejsze zapiski z księgi miejskiej Pleszewa (1428-1444), wyd. T. Jurek, Poznań 2011.

Najstarsza pleszewska księga radziecka. Zapiski z lat 1485-1519, wyd. A. Kozak, Poznań 2014.

Prawo magdeburskie miasta Pleszewa, wyd. W. Maisel, „Studia i Materiały do Dziejów Wielkopolski i Pomorza" [1963], t. VIII, z. 1 [15], s. 67-82.

Przeracki J., Księga ławnicza sądu przedmiejskiego Nowego Miasta Torunia z lat 14441457, [w:] Studia nad dziejami miast i mieszczaństwa w średniowieczu, t. II: Studia ofiarowane Profesorowi Antoniemu Czacharowskiemu w sześćdziesiata piata rocznice urodzin i czterdziestolecie pracy naukowej, red. R. Czaja, J. Tandecki, Toruń 1996, s. 309-330.

Samsonowicz H., Średniowieczne księgi sądowe małych miast w Polsce, [w:] Homines et societas. Czasy Piastów i Jagiellonów. Studia ofiarowane Antoniemu Gasiorowskiemu w sześćdziesiąta piąta rocznice urodzin, red. T. Jasiński, T. Jurek, J. M. Piskorski, Poznań 1997, s. 479-484.

Słowiński J., Kancelarie wsi małopolskich od końca XIV do schyłku XVIII wieku, „,Studia Źródłoznawcze" 1991, t. XXXI, s. 25-35.

Warschauer A., Die mittelalterlichen Stadtbücher der Provinz Posen, "Zeitschrift der Historischen Gesellschaft für die Provinz Posen" 1896, t. XI, s. 349-382.

Wiślicz T., Księgi sąowe wiejskie z XV wieku, [w:] Świat średniowiecza. Studia ofiarowane Profesorowi Henrykowi Samsonowiczowi, red. A. Bartoszewicz, G. Myśliwski, J. Pysiak, P. Żmudzki, Warszawa 2010, s. 290-298. 